\title{
GUIDELINES ON HOME CARE PROVIDED TO OLDER PEOPLE BY GERIATRICIANS, SPECIALISTS IN GERONTOLOGY AND OTHERS HEALTH PROFESSIONALS
}

\section{Orientações para atendimento domiciliar a idosos por geriatras, especialistas em gerontologia e outros profissionais da saúde}

With the social isolation recommended by health authorities as a measure to control the SARS-CoV-2 pandemic, home care for older adults and those with chronic diseases, groups with higher mortality when affected by COVID-19, is currently a relevant tool to be used by health care professionals $(\mathrm{HCPs})$ for the evaluation and control of their patients. ${ }^{1-3}$

Measures are important for the prevention of infection by the new coronavirus for both the HCPs and the patient. As the incidence and recommendations of health authorities may change, follow the guidelines of the Ministry of Health and the Department of Health in your state and/or city. ${ }^{4}$

It is essential that HCPs are able to provide guidance to users during home care in relation to preventing contagion, identifying suspected COVID-19 cases, offering home care, or indicating hospitalization in necessary cases.

\section{SCHEDULING APPOINTMENTS}

The HCP that performs home care should take standard precautions to track respiratory symptoms in older adults when scheduling home visits. If the patient has respiratory symptoms and the care is not urgent, postpone the appointment until the condition is resolved. ${ }^{1}$

\section{CARE OF PATIENTS WITHOUT RESPIRATORY SYMPTOMS OR WITHOUT PRIOR CONTACT WITH A PERSON WITH COVID-19}

The HCP can use a surgical mask well adjusted to the face when in the same environment and during the patient's handling. Masks should not be touched or handled during use. If the mask becomes wet or soiled with secretions, it should be changed immediately.
The HCP should be kept at a distance of 2 meters from the patient during the conversation and hands should be cleaned with soap and water and/or 70\% gel alcohol before and after touching the patient.

It is important that all objects used in the care of patients be cleaned with liquid alcohol 70\%, such as pen, sphygmomanometer, stethoscope, pulse oximeter, thermometer, professional gerontologist materials, stamp, plastic briefcase with prescription forms, exam request guides, smartphones and others, and avoid sharing them. It is necessary that the $\mathrm{HCP}$ be rigorous with the preventive measures to avoid the contagion of the older patient.

\section{CARE OF PATIENTS WITH RESPIRATORY SYMPTOMS OR WITH PRIOR CONTACT WITH A PERSON WITH SUSPECTED OR CONFIRMED COVID-19}

Material for sanitizing medical and health care equipment, the car, and professionals themselves: ${ }^{5,6}$

- Spray with $0.1-0.2 \%$ sodium hypochlorite solution. Practical tip: $100 \mathrm{~mL}$ of sanitary water $2 \%+900 \mathrm{~mL}$ of water $=1 \mathrm{~L}$ of $0.2 \%$ sodium hypochlorite solution). This solution has low cost, is available and can be used to sanitize door handles, window roll up handles, gait, steering wheel, panel, car key;

- Spray with $70 \%$ alcohol solution;

- $70 \%$ alcohol gel.

For hand sanitizing before and after touching the car door handles, home access gates, elevators, door handles:

- Personal Protective Equipment (PPE) kits for each appointment containing:

- 1 disposable cap;

- 1 eye protective goggles; 
- 1 disposable long-sleeved apron;

- 1 N95 or PFF2 mask;

- 1 surgical mask (wear on top of N95/PFF2);

- 2 pairs of gloves.

- Clothes: use long-sleeved shirts covering up to the wrist and Crocs type closed shoes. Remove the clothes before entering the house and sanitize with sodium hypochlorite. Note: bind hair, remove adornments, remove beard.Make use of N95 or PFF2 mask at the exit of the vehicle and keep it throughout the service, until the return to the car. The ideal is the one-time use of this mask because of the possibility of the virus remaining on its surface. Because of the lack of masks of this specification, it is recommended to superpose a surgical mask, which should be removed and discarded after treatment, and the N95/PFF2 needs to be packaged in an appropriate sealed container, so it can be reused for up to 15 days. When the N95/PFF2 mask shows signs of being wet, it should be discarded. In hot climates and users with intense sweating, it is sometimes impossible to reuse. When N95 masks are absolutely unavailable, single-use surgical masks should be used. Keep medical and other health care equipment in a suitcase that can be sanitized. Sanitize medical equipment before and after use with $70 \%$ alcohol. On the way back to the vehicle, sanitize your hands before touching the handle. Remove the N95 or PFF2 mask using a container as support and store it in that container;

- Gowning procedure:

1. Sanitize hands;

2. Put on the first pair of gloves;

3. Put on a waterproof apron. Attach the neck and then the cord on the side;

4. Place surgical mask on the N95 or PFF2 mask;

5. Put on protective goggles;

6. Wear a cap covering the ears;

7. Put on the second pair of gloves, covering the sleeves of the apron.

- De-gowning procedure:

1. Request garbage bag at patient's home for disposal of disposable PPE;

2. Sanitize the outer gloves;

3. Remove the apron and outer gloves simultaneously, rolling them, always taking the inner part of the apron;

4. Discard the apron and outer gloves in the garbage bag;

5. Remove cap from back to front and discard it in the garbage bag;

6. Take off goggles and put it in a plastic container;

7. Remove surgical mask and dispose of it in the garbage bag;
8. Sanitize the inner gloves;

9. Remove the inner gloves and dispose of them;

10. Sanitize the hands;

11. Handle plastic case with the printed matter, stamp and pen for recipes and necessary examination requests;

12. Sanitize the hands.

\section{PAYMENT OF PROFESSIONAL FEES}

Prefer bank transfer as a form of payment of fees.

Statement update

Document updated on April 9, 2020.

Special Commission COVID-19, Brazilian Society of Geriatrics and Gerontology (Sociedade Brasileira de Geriatria e Gerontologia - SBGG)

\section{Carlos André Uehara}

President of the SBGG

Renato Gorga Bandeira de Mello

Scientific Director of the SBGG

Maisa Carla Kairalla

Coordinator of the Special Commission COVID-19 of the SBGG

Daniel Christiano de Albuquerque Gomes Member of the Special Commission COVID-19 of the SBGG

Jarbas de Sá Roriz Filho

Member of the Special Commission COVID-19 of the SBGG

Valmari Cristina Aranha

Member of the Special Commission COVID-19 of the SBGG

Karina Silveira de Almeida Hammerschmidt Member of the Special Commission COVID-19 of the SBGG

\section{Paulo José Fortes Villas Boas}

Member of the Special Commission COVID-19 of the SBGG 


\section{REFERENCES}

1. American Academy of Home Care Medicine. AAHCM Leadership Communication Re: COVID-19 [Internet]. American Academy of Home Care Medicine; 2020 [Accessed in 3 abr. 2020]. Available from: https:// www.aahcm.org/page/LeadershipCOVID19

2. Yang M, Thomas J, Zimmer R, Cleveland M, Hayashi JL, Colburn JL. Ten Things Every Geriatrician Should Know About House Calls. J Am Geriatr Soc. 2019;67(1):139-44. https://doi.org/10.1111/jgs.15670

3. Cornwell T. Home-Based Primary Care's Perfect Storm [Internet]. Home Centered Care Institute; 2019 [Accessed in 3 abr. 2020]. Available from: https://www.hccinstitute.org/app/uploads/2017/10/Web-HCClPerfect-Storm-White-Paper.pdf?×85650

4. Brasil. Ministério da Saúde. O que é coronavírus? (Covid-19) [Internet]. Brasil: Ministério da Saúde; 2020 [Accessed in 3 abr. 2020]. Available from: https://coronavirus.saude.gov.br/
5. Centers for Disease Control and Prevention. Infection Control. Isolation Precautions. Appendix A. Type and Duration of Precautions Recommended for Selected Infections and Conditions [Internet]. Centers for Disease Control and Prevention; 2019 [Accessed in 15 mar. 2020]. Available from: https://www.cdc.gov/infectioncontrol/ guidelines/isolation/appendix/type-duration-precautions.html

6. Centers for Disease Control and Prevention. Preparing for COVID-19: Long-term Care Facilities, Nursing Homes [Internet]. Centers for Disease Control and Prevention; 2020 [Accessed in 15 mar. 2020]. Available from: https://www.cdc.gov/coronavirus/2019-ncov/healthcare-facilities/ prevent-spread-in-long-term-care-facilities.html 